\title{
一定軸荷重と強制部材角を受ける鋼柱の高温時の崩壊挙動 COLLAPSE BEHAVIOR OF STEEL COLUMNS SUBJECTED TO INDUCED JOINT TRANSLATION ANGLE AND CONSTANT AXIAL LOAD AT HIGH TEMPERATURE
}

\author{
岡 部 猛*, 安部武雄** \\ Takeshi OKABE and Takeo AVE
}

\begin{abstract}
An experimental and analytical study was conducted to evaluate the effects of induced deformation caused by the thermal elongation of connected heated steel beams on the buckling behavior of steel columns at increasingly higher temperatures under a constant axial load. The buckling tests were performed using steel columns (SN490B JIS grade) with rectangular cross-sections. The result of tests indicated that the reduction in the column failure temperature Tcr due to induced deformation can be from $10^{\circ} \mathrm{C}$ to $50^{\circ} \mathrm{C}$, depending on the axial force ratio. And also, the behavior of tests were simulated by the one-dimensional finite-element procedure, and the evaluation of the effect of induced joint translation angle on the column failure temperature Tcr was carried out.
\end{abstract}

\section{Keywords: Induced displacement, Buckling load, Creep strain at high temperature, Fire-safe design. Steel structure 強制変形，座屈荷重，高温クリープひずみ，耐火設計，鋼構造}

\section{1.はじめに}

鋼構造建築物に発生した火災により加熱された鋼はり部材は材長 万向に熱膨張し、隣接する柱部材に水平方向の強制変位を与えるの で、柱部材は軸荷重上同時に逆対称形に近い曲げモーメントを受け て変形する $1,2,8)$ この時、柱部材の柱頭柱脚部分には早期に降伏領 域が発生して成性が低下すると上もに、強制変形によるたわみ上柱 の軸荷重による付加曲げモーメント ( P - ס効果)が発生する。この ように考えると、火災時の鋼柱材の鉛直荷重支持能力は、強制変形 を受けない中心圧維状態の柱材の鉛直荷重支持能力よりも相当に低 下寸ることが悬念される。

加熱された鋼はり部材の熱膨張による強制変形が、鋼柱部材の鉛 直荷重支持能力に及ぼす影響を系統的かつ分析的に取扱つた研究例 は数少ない。著者らの知る限りでは、数值解析的研究としてBailey ${ }^{3}$ や鈴木他4の研究例が見い出されるのみであり、実験的研究に至って は皆無である

文献3,4) は何れも火災加熱を受ける鋼骨組を対象上し、加熱され るはり部材の長さ等の柱部材の崩壞温度に影響を及ぼすと考えられ る各種の要因を系統的に設定し、その影響度を調べたものであり、 いくつかの有用な知見が示されている。今後、これらの数值解析モ デルのみで導かれた知見をより確実なものとするためにも物理実験
的研究による裏付けや検証が必要上考えられる

このような観点から筆者等は文献17)において、はり部材の熱膨張 による強制変形を受ける柱部材の挙動を、両材端回転固定で強制部 材角を受ける柱部材の挙動に理想化した実騃装置を開発し、常温か ら高温に至る各種の一定温度下で強制部材角 $\mathrm{R}$ 已軸方向の荷重Pを同 時に加える加力実娩（(A)一定温度実験上呼ぶ）を行い、最大軸荷重 P maxに及ぼす部材温度 T と強制部材角 $\mathrm{R}$ の影響を調べた なお、こ の研究では強制部材角を全く加えない実験( 中心圧縮実騃 $R=0.0$ ) 已 強制部材角 $R$ を加える実娩 $(R=1 / 50,1 / 25)$ の両方を行い、両者の結果 を比較することにより最大荷重に及ぼす強制部材角の影響を実娩的 に直接明らかにした

その結果、柱部材温度が常温の場合には強制部材角が $\mathrm{R}=1 / 25$ ほ 加わることで最大軸荷重が $10 \%$ 以上も低下することが明かとなっ た 一方、柱部材温度が $400^{\circ} \mathrm{C}$ 以上の高温域の場合は強制部材角Rに 上る最大軸荷重 $P \max$ の低下流々 $3 \%$ 程度と僅かなものになるこ上 も明らかになった，このように強制部材角Rの高温時の最大軸荷重 P maxの低下に及ぼすの影響が小さい上いうことは、文献9〜16)等で 得られている両端ビン支持で中心圧縮荷重条件で行った柱の実験資 料を耐火設計に有効に活用できることを示すものであった

本研究は文献17)の続編であり、文献17)で行った(A)一定温度実験

\footnotetext{
* 熊本大学:工学部䍗境システム工学科 助教授・T博

** 東京工業大学建築物理研究センタ一- 助教授. 工博
}

Assoc. Prof., Department of Architecture and Civil Engineering, Faculty of Engineering, Kumamoto University, Dr. Eng.

Assoc. Prof., Structural Engineering Research Center, Tokyo Institute of Technology, Dr. Eng. 

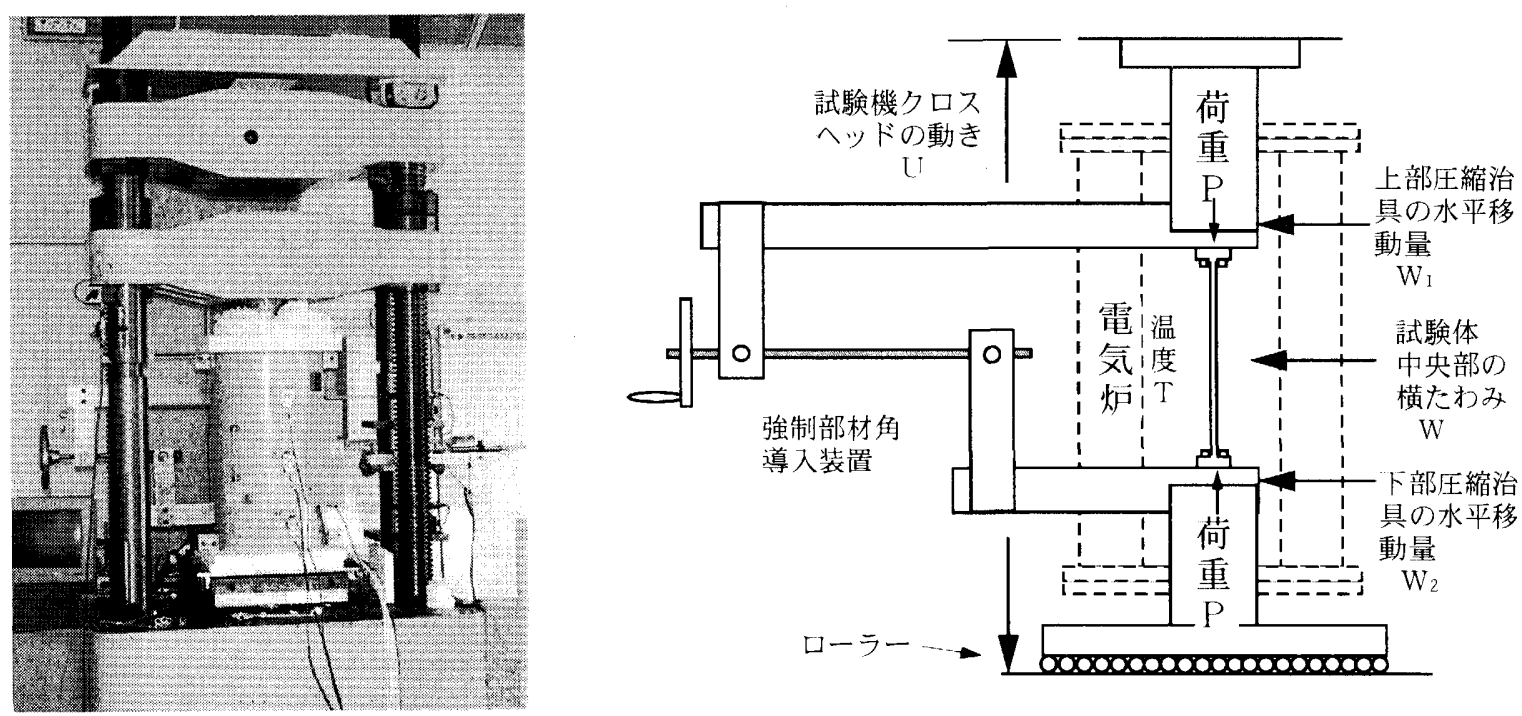

図 1 強制部材角を受ける柱材の座屈实験装琶の全景と概要

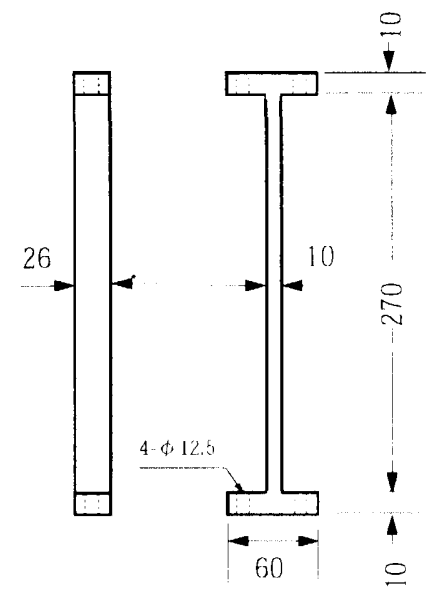

図 2 試験体の寸法（単位： $\mathrm{mm}$ ) $\lambda=0.6$

に比較してより現実の火災に近い条件と思われる、一定軸荷重Pが加 わる状態で温度 $\mathrm{T}$ 上強制部材角 R上が同時に漸増する場合の鋼柱材の 座屈崩壊実験（以下、(B)一定荷重漸増温度実娩上呼ぶ）を行い、崩 壊挙動に及ぼす強制部材角の影響を検討するものである：本論文之 文献17)の耐方の実験で得られた結果は、強制部材角Rを受ける鋼 柱材の高温時の荷重支持能力を考察するための相互補完的資料上な るもりである

従って、本論文の主目的は、文献17) 上同様に鋼柱部材の崩壊挙動 に及ぼす強制部材角り影響を実娩的に明らかにするものであり、ま た、数值解析により実験挙動をシミュレートすることにより実験挙 動の考察の一助上するものである

\section{2. 実験方法及び試験体}

図 1 と図 2 に高温座屈実娩装置の概要と柱試娩体の寸法を示す この装置と試䮖体㳉文献17) と同じものであり、試娩体に軸荷重Pを 加える压縮用治具、部材角 $R=\Delta / \mathrm{L}$ を与えるL型の腕、筒型電気炉 (内法直径 $20 \mathrm{~cm}$ 、高さ $60 \mathrm{~cm}$ ) 等を万能試娩機の)加力フレーム内に

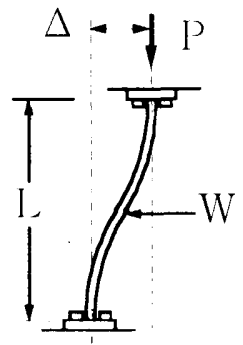

造験条作：12 種類

(i) 一运軸攸禹P 4 種類 P/P YRT $0.2 .0 .3,0.4,0.5$

(ii) 強制部材仔 $\mathrm{R} \quad 3$ 種類 $R=\Delta / 1.0 .0 .1 / 50.1 / 25$ の組命せ

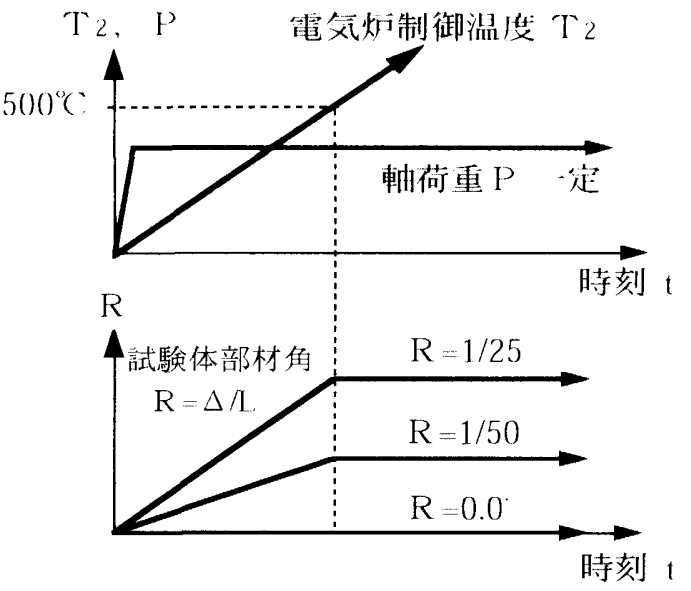

(B)一定荷重漸増温度実験

図 3 実験条件と実験の制御方法

組み込んだものである、本実験装置では、試験体压縮用の治具に取 付けたL型の腕をネジ切り棒で連結して、それを回転させるこ上によ り手動で強制部材角を加える方法を採った

図加らも明かなように、柱試娩体の境界条件汇上下端完全固定で あり、従って座屈長さは柱試娩体全長の半分になる：なお、本実娩 の柱試騃体も文献17) 上同じく常温時の無次元化有効細長比（以下、 
表 1 試駼体鋼板の化学成分（ミルシート值）（\%）

\begin{tabular}{|c|c|c|c|c|c|}
\hline \multirow{2}{*}{ Symbol } & $\mathrm{C}$ & $\mathrm{Si}$ & $\mathrm{Mn}$ & $\mathrm{P}$ & $\mathrm{S}$ \\
\cline { 2 - 6 } & \multicolumn{3}{|c|}{$\mathrm{x} 100$} & \multicolumn{2}{|c|}{$\times 1000$} \\
\hline SN490B & 18 & 34 & 126 & 14 & 4 \\
\hline
\end{tabular}

表 2 試験体鋼板の機械的性澌（常温引張試験）

\begin{tabular}{|c|c|c|c|c|}
\hline $\begin{array}{c}\text { TEST PIECE } \\
(\text { Plate 28mm) }\end{array}$ & $\begin{array}{c}\mathrm{E}_{\mathrm{RT}} \\
(\mathrm{GPa})\end{array}$ & $\begin{array}{c}\sigma_{\mathrm{v} \text { RT }} \\
(\mathrm{MPa})\end{array}$ & $\begin{array}{c}\sigma_{\mathrm{uRT}} \\
(\mathrm{MPa})\end{array}$ & $\begin{array}{c}\text { Elong }{ }_{\mathrm{RT}} \\
(\%)\end{array}$ \\
\hline SN490B & 208 & 332 & 510 & 31 \\
\hline
\end{tabular}

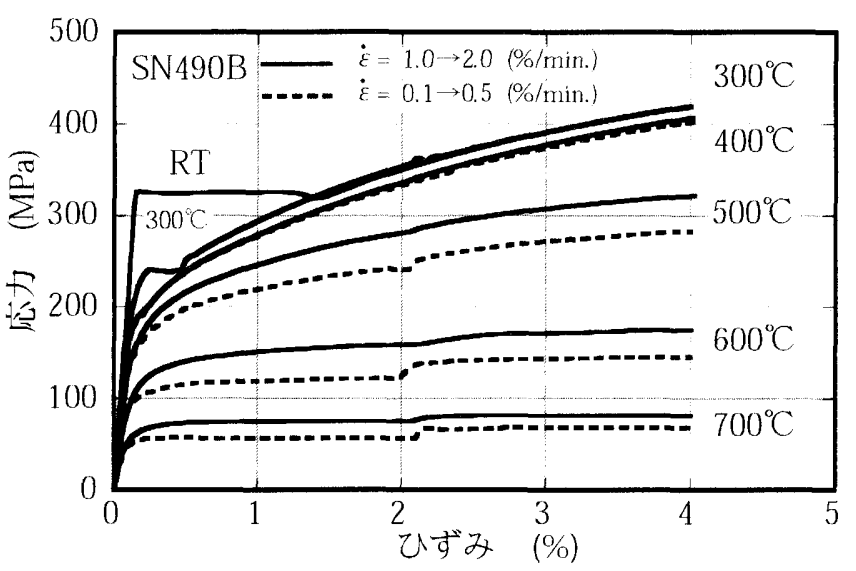

図4＼cjkstart応力ひずみ関係（一定温度下引張試験）

単に細長比と呼ぶ） $\lambda=0.60$ ものを用いた

図 3 に本論文で用いた実験条件とその制御方法を示す，文献17)で 行った実験注 $(A)$ 一定温度実験であるが、本実験は $(B)$ 一定軸荷重漸 増温度実騃である。

この実騃では、鋼柱試娩体を実験装置にセットした後、最初に軸荷 重到所定の軸力比（ $\mathrm{n}=\mathrm{P} / \mathrm{P}_{\mathrm{vRT}}=0.2,0.3,0.4,0.50$ いずれか）に従って 柱試騃体に加え，その後一定値に保持する，次に電気炬の内部温度 $\mathrm{T}$ を温度速度 $5{ }^{\circ} \mathrm{C} /$ 分のベースで線形に上昇させながら、同時に強制部材 角 $\mathrm{R}$ 手動で加える：この時、強制部材角 $\mathrm{R}$ の時間変化は電気炬の内 部温度Tに比例するものとし、その大きさ注電気炉内部温度 $\mathrm{T}$ が 500 ○Cに達する時点でR=0.0、1/50、1/25 となるような 3 種類を設定する $\mathrm{R}=0.00$ 場合は強制部材角 $\mathrm{R}$ を加えない中心圧縮実娩であり、強制部材 角が $\mathrm{R}=1 / 50 、 1 / 25$ 上加わる場合の結果已直接比較するこ上により、そ の影響を明かにする。なお、電気炬内部温度が500 Cを超えた時点で は強制部材角 Rの増加を中止し一定值に保持する

実騃は柱試騃体が温度上昇に伴い一定軸荷重 $\mathrm{P}$ を支えられなくなり 崩壊するまで継続し、柱試騃体が崩壊する時点の柱試験体中央点の中 心温度を崩壊温度 T c r とする

なお、本論文では 4 種類の軸力比 $n=0.2 ， 0.3 ， 0.4 ， 0.5$ に対して電気 炬の内部温度 $\mathrm{T}=500^{\circ} \mathrm{C}$ の時点での 3 種類の強制部材角 $\mathrm{R}=0.0, \quad 1 / 50$, 1/250組合せで 12 体の実娩を行った

実娩時には、万能試娩機の荷重 $P$ 、試験体中央部の水平方向横た わみ $W$ 、上下の圧縮用治具の水平移動量 $W_{1}, W_{2}$ 、試娩機のテーブ

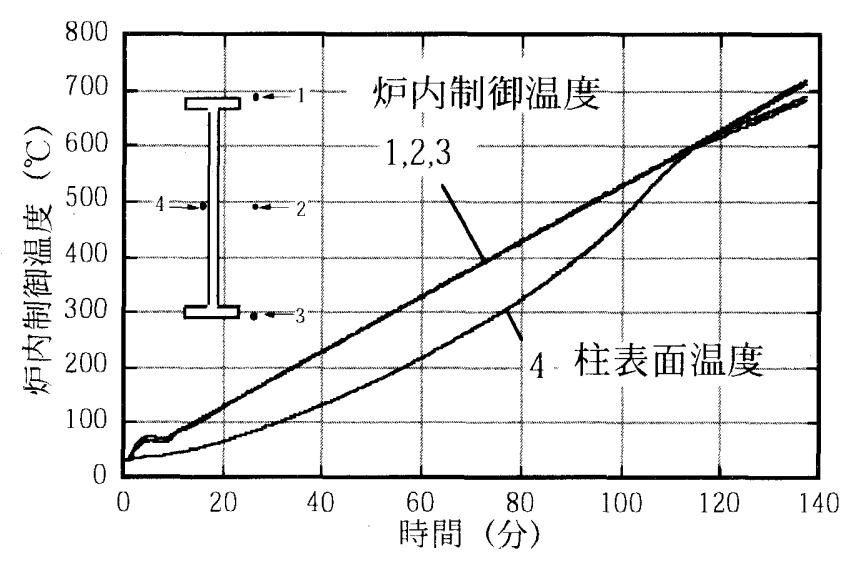

図 5 一定温度実験の温度時刻歴

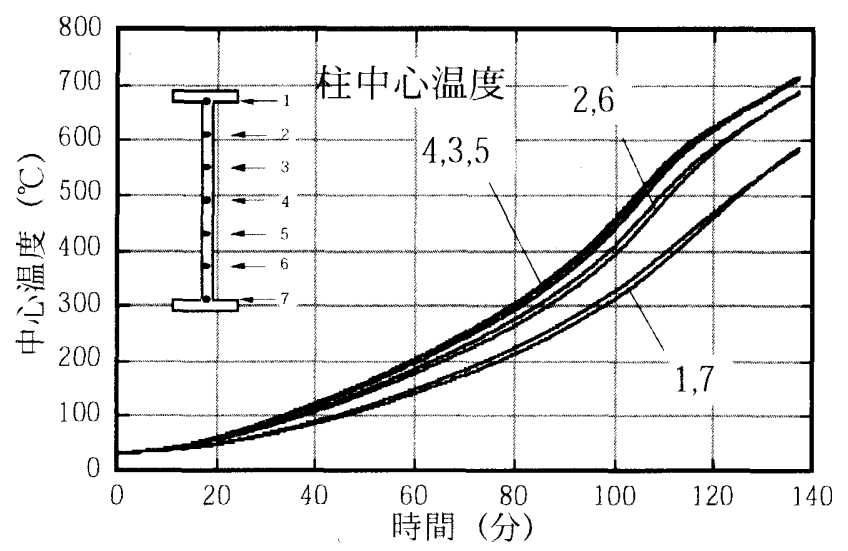

図 6 一定温度実験の温度時刻歴

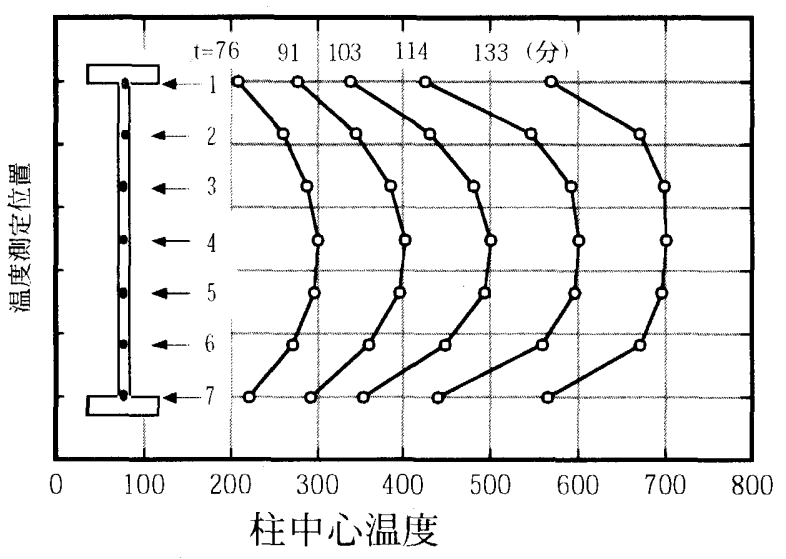

図 7 一定温度実験の温度分布

ルとクロスヘッド間の動きU、ならびに電気炬内部温度や柱試娩体 温度等の時刻歴を 5 秒間隔で測定した，柱試騃体の部材角Rは、上下 の压縮用治具の水平移動量 $W_{1}, W_{2}$ の差上り得られる

試験機テーブル上クロスヘッド間の動きUには、試験体の伸縮量の ほかに試娩機や圧縮治具の熱膨張変形等が含まれており、試験体自身 の伸縮量を正確に表わすものではないしかし、以後簡単のためこの 量を柱伸縮 $U$ と呼ぶここにする

また、試娩体の鋼種は建築構造用鋼材SN490Bであり、文献17)上 同じものである：表 1 に試験体鋼板の化学成分，表 2 に常温時の機 


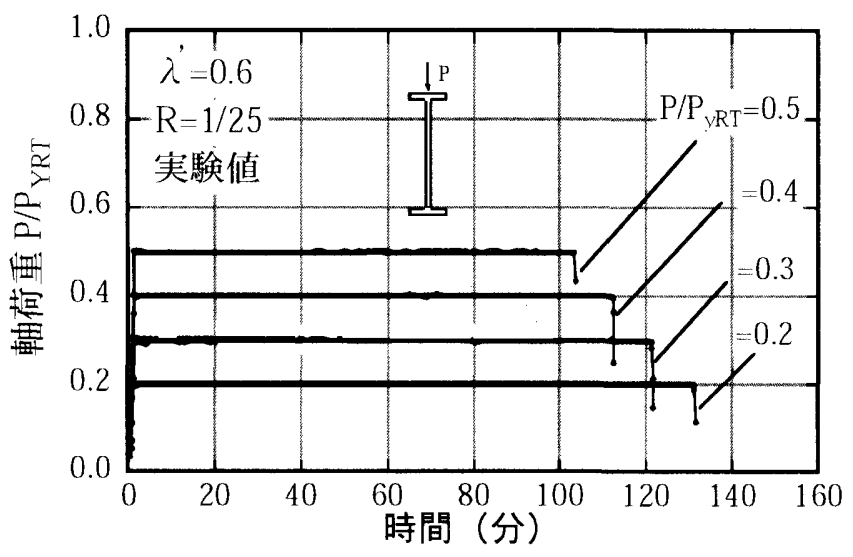

図 8 一定軸荷重P の時刻歴

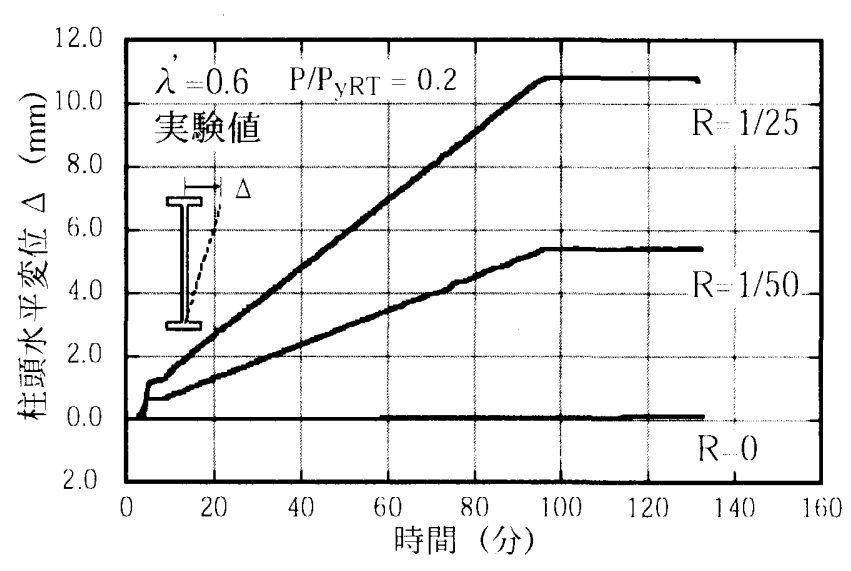

図 9 柱頭水平変位 $\Delta$ の時刻歴

械的特性、図 4 に一定温度下で行った引張試娩により得られた忠う ひずみ関係を示す

次に、電気炬の加熱能力を調べる目的で行った予備加熱寒娩の)結果 在述べる，図 5 フ り加熱パターンを加えた場合の、柱試験体中心温度の測定結果であ るな㧍、この試娩体に軸荷重Pは加えていない また、後述の載荷 加熱実騃では温度測定用のドリル小穴の断面欠損が座屈荷重に及ぼ す影響を考慮して柱試験体の中心温度の測定は行わないが、シミュ レーションに必要な温度分布データはこの実娩結果を用いる

図 5 は、電気炉の制御温度 (上、中、下 3 点) 上柱試騃体中央点の 表面温度の時刻歴であり、図6 は、柱試娩体の平行部を材軸方向に6 等分する点の中心温度の時刻歷である、また、図ては柱試娩体中央部 の中心温度が $300,400,500,600,700^{\circ} \mathrm{C}$ 上なった時点での柱試騟体中心温 度の材長方向の分布図である。

これらを見ると、文献17)の(A)一定温度実娩の場合よりも今回の(B) 一定軸荷重漸增温度実娩の場合の方が、柱試娩体の上下端部の温度が 上がりにくいこ上、中央点已材端部の温度差は $100^{\circ} \mathrm{C}$ 以上になり、試 娩体全体から見て均一温度分布からは程遠いこ上が分かる。

従って、これらの試娩体の座屈崩壊時の温度（崩壊温度） T crを評 価する場合は、実験に㧍いては柱材内部の温度分布は完全に均一では なく、図のような分布をしているこ上を考虑に入れる必要がある、本 報告では、先に述べたように上りあえず崩壊時の柱試娩体中央部の温 度を崩壊温度 Ter として示卞
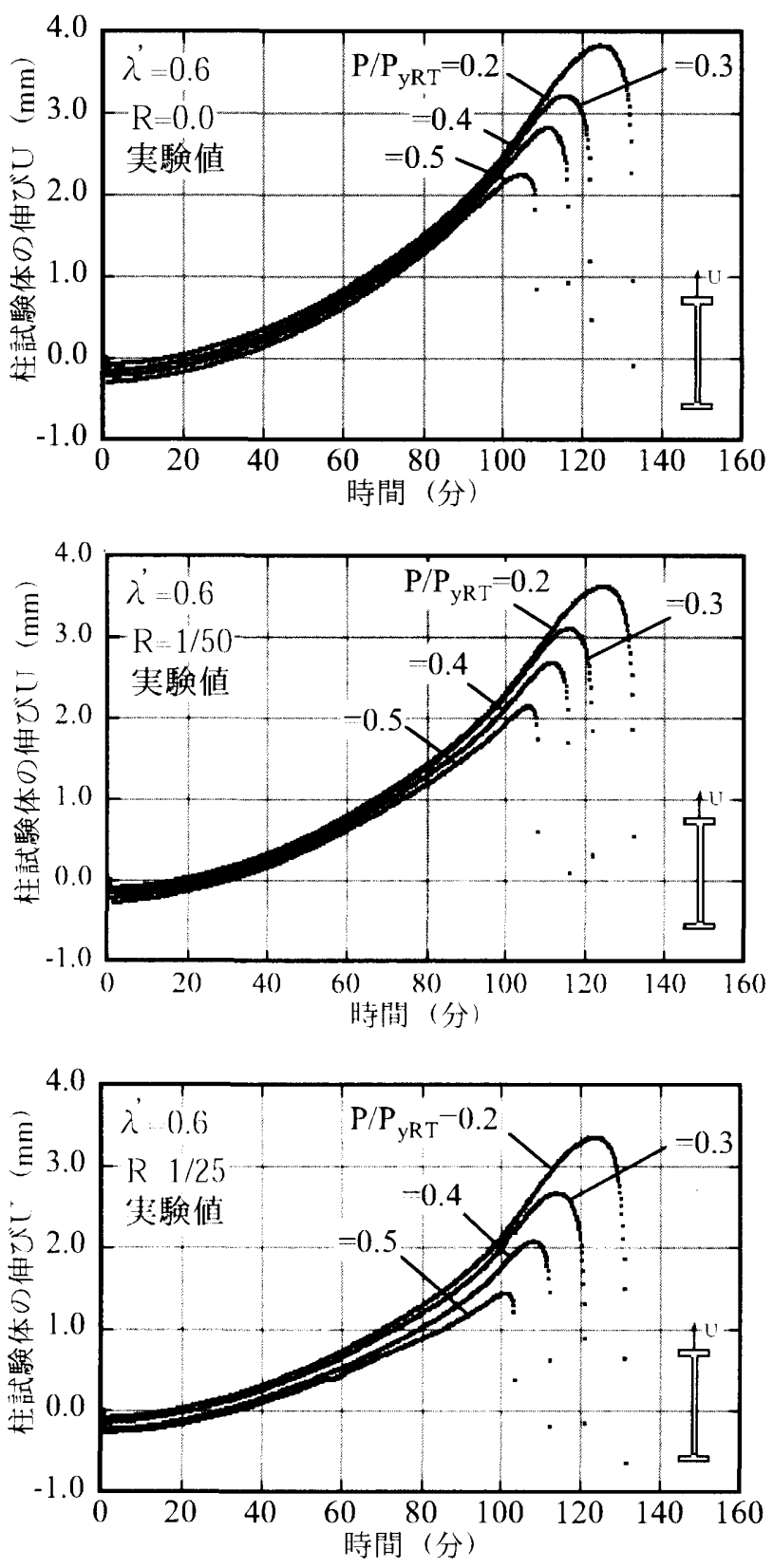

図10 柱試験体の伸樎墨Uの時刻歴

\section{3、実験結果の考察}

以下、本実娩で得られた実験結果を示す

図8 は一定軸荷重 P O時刻歴の例であり、強制部材角 $R=1 / 25$ の場 合である。この実娩の柱崩壊時には試騟体は軸荷重を支持するここが できなくなり、試娩機の軸荷重Pが急激に低下寸ることが分かる，強 制部材角 $\mathrm{R}=0.0,1 / 50$ の場合も同様の結果となった

図 9 は柱試験体の柱頭部上柱脚部の相対水平変位 $\Delta=W 2-W 1 \sigma$ 時刻歴の例であり、一定軸荷重 $\mathrm{P}$ が最も小さい軸力比 $n=0.2$ の場合 のものである。この量 $\Delta$ は、炬内温度 $500^{\circ} \mathrm{C}$ の時点で柱試娩体強制部 材角 $\mathrm{R}=\Delta ， \mathrm{~L}$ が $\mathrm{R}=0.0,1 / 50,1 / 25$ こなるように制御されていること が分かる。なお、本実娩では測定は 5 秒間隔で行われている

図10は柱試娩体の伸縮量Uの時刻歴であり、図11 は柱中央点の水 平変位 (たわみ量) Wの時刻歴である。上中下段の図はそれぞれ強制 部材角 $R=0.0,1 / 50,1 / 25$ の場合に対応している:

これらの図から実験挙動を観察する上、加熱初期の柱試娩体の軸 

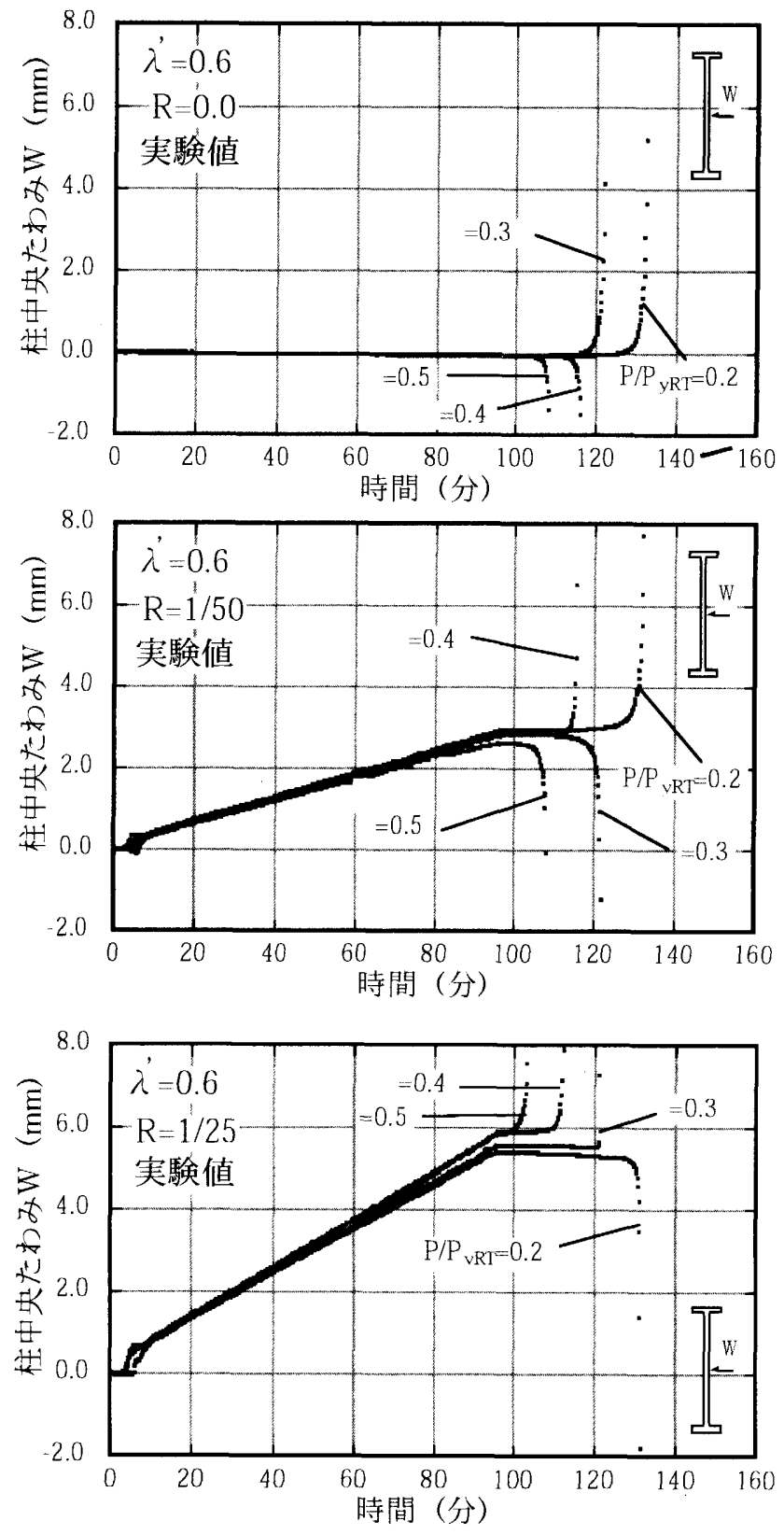

図11 柱中央点の水平变位（たわみ量）Wの時刻歴（実験値）

方向伸縮 Uは柱試験体等の熱膨張のため鋼材温度（図6）に比例し て增加し、崩壊直前に增加が止まる、この時点までの柱中央点の水 平変位 (たわみ量) Wは、図9の柱試娩体の柱頭之柱脚の相対水平 変位 $\Delta$ のぼ半分の値となっており、上下逆対称形の曲げせん断型 の変形をしていることが分かる、また、最終的な崩壊時にはどの強 制部材角Rの柱も、柱伸縮量 Uが隇少するするとともに、柱中央点 の水平変位 (たわみ量) Wは急激に増加する挙動を示している。こ のここは、強制部材角 $\mathrm{R}$ 加えない場合 $(\mathrm{R}=0.0)$ も加える場合 $(\mathrm{R}=1 /$ $50 ， 1 / 25)$ も、崩壊時には上下逆対称の曲げせん断型変形の釣合い状 態からの上下対称形の分岐モードを伴う不安定現象が起っているこ とを示している:なお、図11から分かるように強制部材角Rが加 わっている場合の崩壊挙動は、いずれの場合も電気炉内温度が500 C以上になり強制部材角Rが一定值に保持されている時点で起こっ ている。
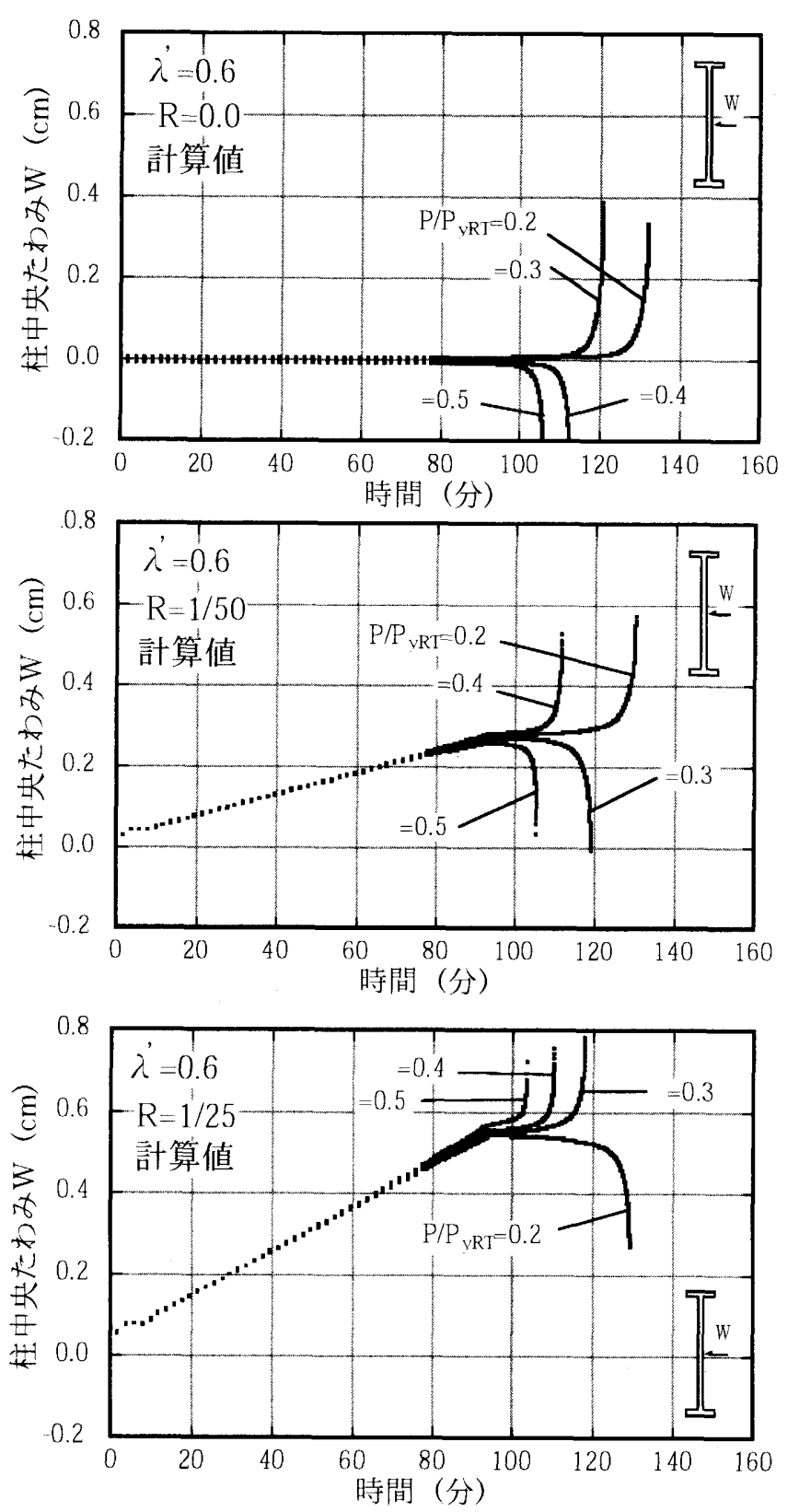

図12 柱中央点の水平变位（たわみ量）Wの時刻歴（計算值）

また、図 10、11より、軸力比 $n=P / P_{y R T}$ が大きい程、早期に崩 壊すること、強制部材角 $R=0.0,1 / 50,1 / 25$ による崩壊時刻の差治 ごないように見えることが分かる。

図13は実験後の試験体の残留変形状態の写真上実測値を強制部材 角 $\mathrm{R}=0.0,1 / 50,1 / 25$ の順に示したものである

これらの写真と図から、強制部材角 $R=0.00$ 場合は上下対称形の 1 次の座屈モード形の変形が残留していること、強制部材角 $\mathrm{R}=1 / 50$, $1 / 25$ の場合は、上下逆対称の曲げせん断型の変形に上下対称形の 1 次の座屈モード型の変形が重ね合わさったような変形が残留してい ることが分かる，従って、図11の柱試験体中央点の横たわみWの図 でも考察したように、強制部材角 $\mathrm{R} か ゙$ 存在する場合 $(\mathrm{R}=1 / 50 ， 1 / 25)$ は、両端固定の柱試験体に部材角Rが加わって起こる上下逆対称形 の曲げせん断変形に、軸荷重Pによる座屈時に上下対称形の分岐モ一 ドが生じて終局状態に至ったと思われる 

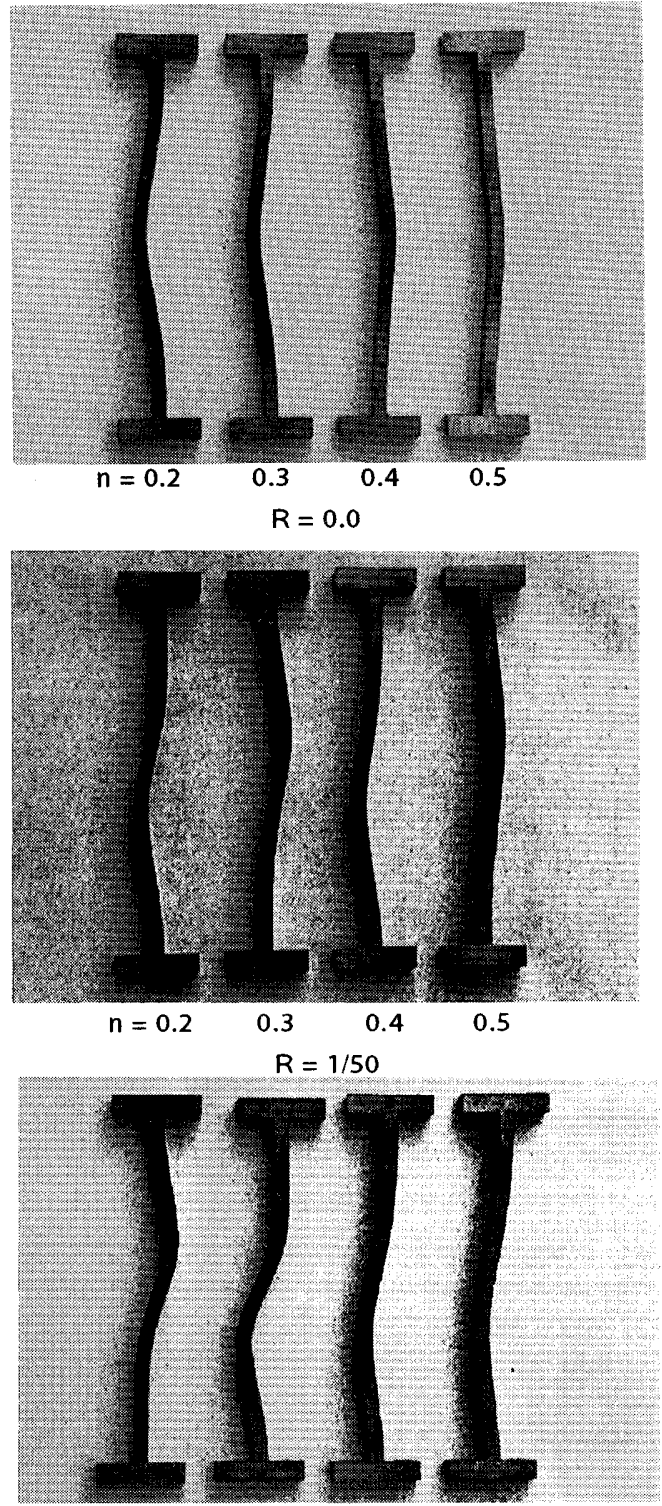

$n=0.2$

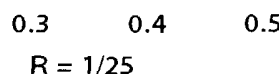

図13 実験後の残留变形状態

図14は、図10こ11で得られた柱崩壊時点の柱試娩体の温度T cr を、強制部材角Rを横軸にとってロ印で示したものである。ただ

し、この場台の柱試娩体の温度分布は図てで示したように均一では ないので、ここで洨文献17）上同様に柱崩壊時点の柱部材中央点の 中心温度を崩壊温度T crとした。

図14より、崩壊温度 T c rに及ぼす軸力比nや強制部材角Rの影響度 が分かる、寸なわち、軸力比听 $0.2 \sim 0.5$ 上変化すると崩壊温度 $\mathrm{T} \mathrm{cr}$ は700 - 500 C 上大きく変化するが、強制部材角 $\mathrm{R} か ゙ 0.0 １ / 25$ 上変化 しても崩壊温度Tcrはあまり変化しないことが分かる、例えば、軸力 比 $n=0.20$ 場合は、強制部材角が $\mathrm{R}=0.00$ 場合 $2 \mathrm{R}=1 / 25$ の場合上の崩 壊温度の差灌か数度である：また、軸力比 $n=0.50$ 場合でも強制部 材角が $\mathrm{R}=0.00$ 場合之 $\mathrm{R}=1 / 250$ ) 場合との崩壊温度の低下は $50^{\circ} \mathrm{C}$ 程度 こ大きなものではない

\section{4. 実験挙動の数値解析的検討}
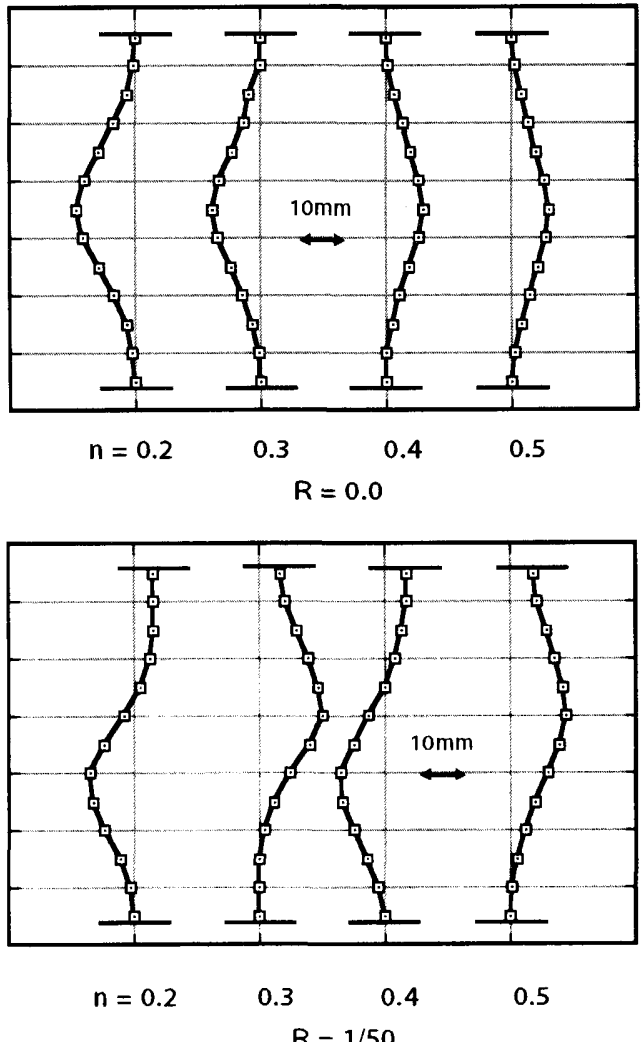

$R=1 / 50$

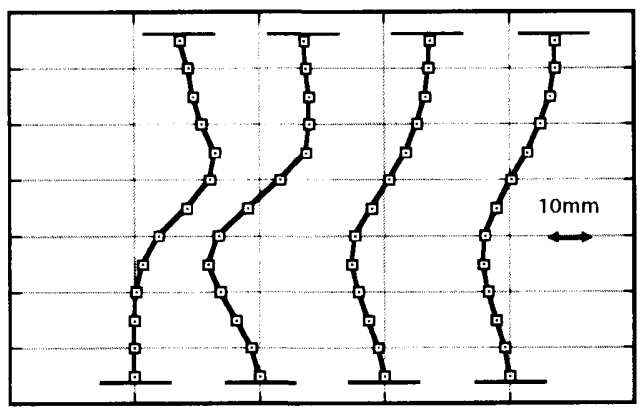

$\begin{array}{llll}\mathrm{n}=0.2 & 0.3 & 0.4 & 0.5\end{array}$

$R=1 / 25$

(写真および測定値)

本研究で用いた熱変形解析法 7,8)、高温時の鋼材の特性 5,6$)$ 、解析 モデルには、材長Lの5,000分の1の最大振幅を持つ両端固定の中心圧 縮材の 1 次座屈モード波形の微少な初期たわみを与えたここ等、全 て文献17)と同様であるので、これらの説明は省略する

以下、数值解析で得られたシミュレーション結果を示す

図12 は柱中央点の水平変位（たわみ量）Wの数值計算結果であ る、ここでは高温クリーブを考虑した解析結果( しているなお、図11から分かるように笑験においては崩壊時のた わみWの起こる方向に規則性は見られない，従って、数值計算では 実験で横たわみWが生じた方向に微小な初期たわみを与えることに より、数值解析のたわみWの生じる力向を実騒結果と合わせて示し てある

図120計算結果と図11 の実験結果とを比較する之、崩壊の起こ る時刻や変形挙動の様子はともに良く対応しており、高温時の銅材 の特性を考虑した一次元有限有限要素法による数値計算法で実験挙 


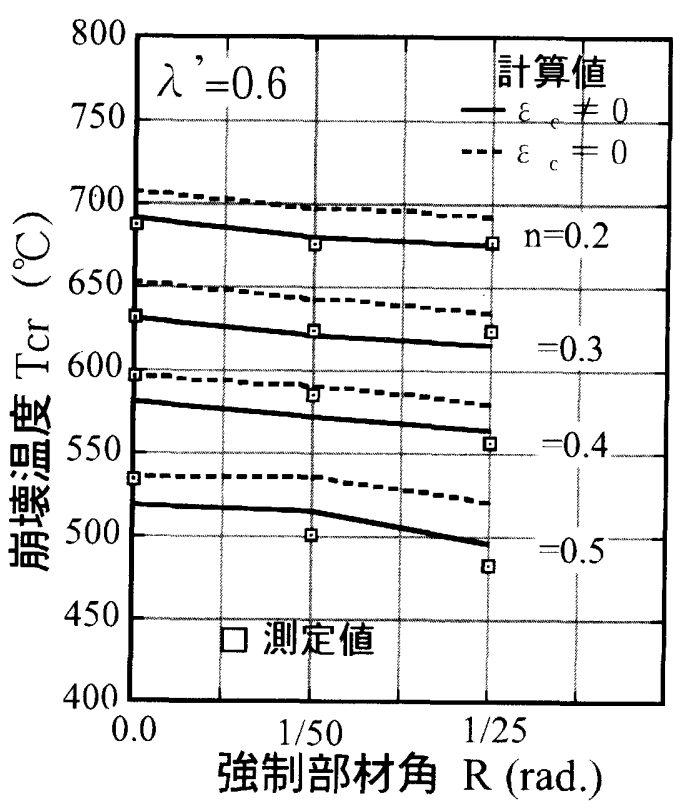

図14＼cjkstart座屈温度と強制部材角

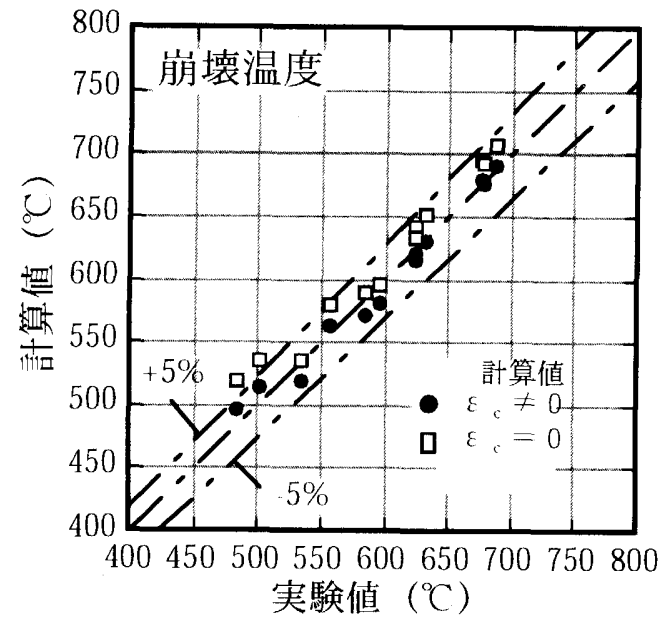

図18 座屈温度と高温クリープ

\section{動を極めて精度良くシミュレートできるここが分かる}

図14には、図12 で得られた数值計算による柱崩壊時点の柱試娩 体の温度Tcrも示されている。数值計算では、高温クリーブを無視し た解析 ( $\varepsilon c=0)$ を破線で、考慮した解析 ( $\varepsilon c \neq 0)$ を実線で示し ている、この図より、高温クリーブを考慮した解析（ $\varepsilon c \neq 0$ 、実 線) は高温クリーブを無視した解析（ $\varepsilon \mathrm{c}=0$ 、破線）よりも安全側 であり、かつ実験結果の り印に良く対応しているここが分かる， 従って、実験の崩壊温度Tcrを数値計算により精度良くシミュレート するために法、高温クリーブ現象を考慮する必要があることが分か る。

図 15,16 は数值計算により得られた軸力比 $n=0.2 \sigma$ 場合の中心圧縮 $\mathrm{R}=0.0$ の場合之強制部材角 $\mathrm{R}=1 / 25$ の場合の柱試娩体の変形図を示し たものである。ビちらの図も実験開始後100分までを左図に、100分 以降の崩壊に至る様子を右図に示している。なお、図16の左図より 計算モデルでも実䮖と同様に柱脚部分に左向きの強制変位が加えら れて部材角Rが発生しているここが分かる

図15,16の右図を観察する上、中心圧縮 $(R=0.0)$ )場合は、崩壊時

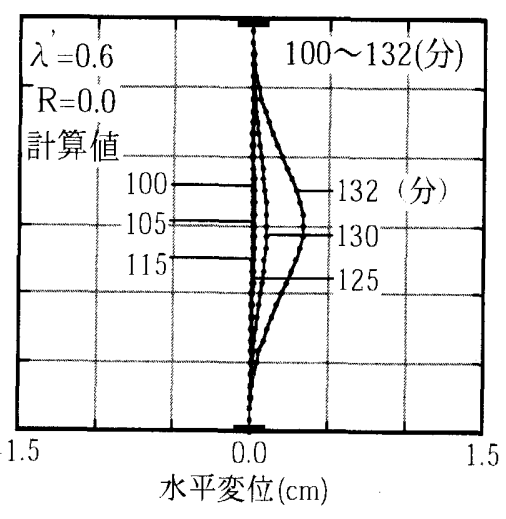

図 15 变形図 $(n=0.2, R=0.0)$

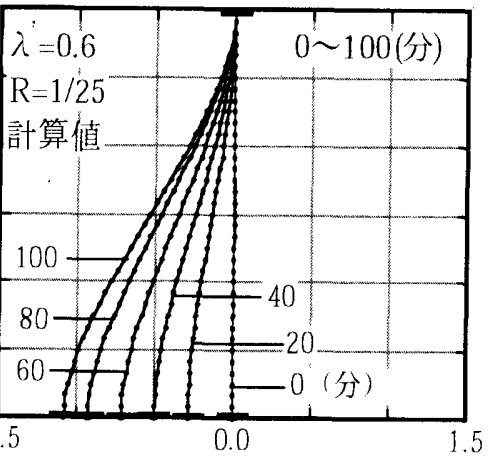

水平変位 $(\mathrm{cm})$

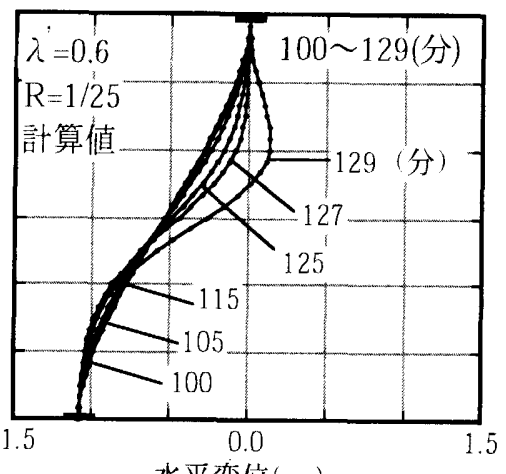

水平変位 $(\mathrm{cm})$
図16 变形図 $(n=0.2, R=1 / 25)$

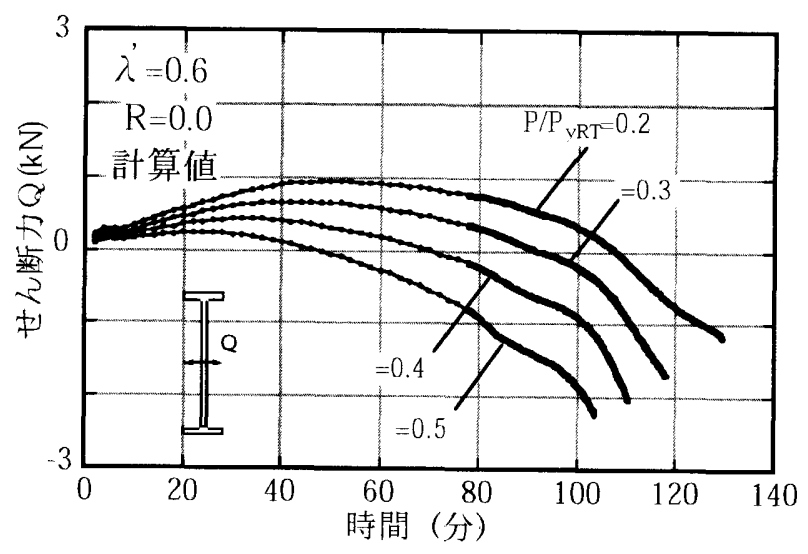

図17せん断力の時刻歴 $(R=1 / 25)$

には上下端固定の中心王縮柱の1次の座屈モード状の変形が見られ る: また、強制部材角 $(R=1 / 25)$ の場合は、当初は上下逆対称形の曲 げせん弾型の变形を示しているが、崩壊時には上下対称形の変形増 分が加わる形の不安定現象が起っているここが分かる

図17涊、数値計算で得られた強制部材角 $\mathrm{R}=1 / 25 \sigma$ 場台の柱部材の せん断力の時刻歴である，軸力比几よって程度の差はあるが、加熱 初期の柱試娩体のせん断力 $\mathrm{Q} は$ 途中で力向を変えて、崩壊時には全 く逆方向を向いていることが分かる，従って、この場合の終局的な 崩壊時挙動は、当初強制部材角Rを与えるために加えた上下逆対称 形の曲げモーメントが分布した状態で起こっているのではないこと が分かる

最後に、実験と数值計算による崩壊温度を図18 比較して示した この図は、実験値を横軸に数值計算值を縦軸にこって表したもので 
ある、ただし、数值計算值で、高温クリーブを無視した解析值（ $\mathrm{c}=0) を \square$ 印で、考慮した解析值 $(\varepsilon \mathrm{c} \neq 0)$ を印で示している。 この図より、高温クリーブを考慮した解析（の印）で実験值と数\% の差異が見られ、高温クリーブを無視した解析（口印）でも6\%程 度の差異しか見られないこ上が分かる。このように鋼材の高温時の 挙動特性を考慮した数值解析法で実験挙動を極めて精度良くシミュ レートできることが分かる。

\section{5.まとめ}

本研究では、建築構造用鋼材(SN490B)を用いた両端固定支持の矩 形断面鋼柱試験体を対象に、一定軸荷重下で漸増温度已強制部材角 上を同時に加える鋼柱材の座屈崩壊実娩を行い、柱の崩壊温度に及 ぼす強制部材角の影響を調べた また、数估計算によるシミュレー ションを行い、実験挙動の考察の，助上した，その結果、次のよう な知兒が得られた

[1]一定荷重下漸増温度笑娩0結果加ら、強制部材角 $\mathrm{R}=1 / 50$ 上 $1 /$ 25 の影響による鋼柱の崩壊温度 $\mathrm{T}\left(\mathrm{r}\right.$ の低下は、軸力比 $\mathrm{P} / \mathrm{P}_{\mathrm{VR}} \mathrm{T}=0.20$ 場 合で数度已小さく、軸力比 $\mathrm{P} / \mathrm{P}_{\mathrm{VRT}}=0.50$ 場合でも高々 50 \% 以下であ ることが示された

[2]実娩後の試娩体の残留変形を観察する之、強制部材角 $\mathrm{R}=0.0$ (中心圧縮)の場合は、上下対称形の) 1 次の座屈モードの変形が残留 しており、強制部材角 $\mathrm{R}=1 / 50$ ，1/250)場合は、上下逆刘称の曲げせ ん断変形に上下対称形の1次の坐屆モードの変形が重称合わさった ような変形が残留している，従って、強制部材角Rが加えられたこ こにより当初上下逆対称変形を呈する場命でも、軸力りによる崩壊時 には上下対称形の分岐座屈举動を起こす上考えられる

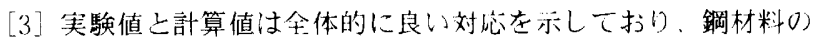
詳細な応力ひずみ関係式を用いた弾塑性クリーフ熱変形解析法によ り、一定軸荷重下で強制部材角之漸增温度を受ける鋼柱材の崩壊に 至る実娩挙動を精度良く予測できることがホさされた

以上の上うに本研究では、一盗軸荷重を受ける矩形断而鋼柱部材 を対象に強制部材角が崩壊挙動に及ぼす影響を調べたその結果、 本実験の範囲では強制部材角Rが鋼柱部材の高温時の荷重支持能力 に及ぼす影響は大きなものではないことが示された

このことは、従来から行われている鋼柱部材の闭端ヒン支持の中 心圧縮載荷加熱実験の結果9１6)を、鋼構造建築物の耐火設計に直接 適用できるという見通しを与えるものである。

一方、本論文の結果は全体曲げ座屈によって軸荷重支持能力が支 配される場合の一資料が得られたこ上を意味するものであって、局 部座屈が全体曲げ座屈上連成して生じる場合の荷重支持能力に及ぼ す強制変形の影響については不明な点が多い，今後の課題とした w
(2)(課題番号12650578)ならびに平成14年度東京工業大学建築物理研 究センター共同研究 (一般共同研究B) の補助を受けた。また、実 験用鋼材料注社)日本鉄鋼連盟より支給を受けた。付記して謝意を表 します。

\section{参考文献}

1 ）日本建策学会：鋼構造耐火設計指針 第6 章、1999.1

2 ) 鉿木弘之: 火災時にお汁る鋼骨組の崩壊温度、日本建策学会構造系論文 集、第477号、pp.147 156、1995.11

3 ) C.G.Bailey: "The Influence of The Thermal Expansion of Beams on The Structural Behavior of Columns in Steel-Framed Structures During a Fire" ,Engineering Structures, Vol.22,pp.755 768, 2000

4) 尾崎文宣、ルアンタヌラック ナラ一、鈴木弘之: 火災加熱を受汁る鋼 構造骨組の崩壤温度（その37 外柱の）座屈崩壊温度）、日本建筮学会大会 学術講演梗概集( 北陸) , pp.39４0、2002.8

5) Fujimoto, M.,Furumura, $\mathrm{F}$, and Ave, T.: "Primary Creep of Structural Steel (SM50A) at High Temperatures" "Trans of A.1.J.,No.306,pp.148 $156,1981.8$

6) Furumura,F, Ave, T, Kim,W, J., and Okabe,T.: "Nonlinear Elasto-plastic Creep Behavior of Structural Steel under Continuously Varying Stress and Temperature." ,J. of Structural and Construction Engineering ,Trans.of A.I.J, No.353,pp. $92 \sim 102,1985.7$

7) 古村福次郎、安部武雄、岡部猛、金和中：火災温度域老考慮した鋼材の 単軸応力 ひずみ関倸式上その鋼構造骨組熱変形解析八の適用、日本建 築学会構造系論文報告集、第363号、pp.110－117、1986.5

81 古村福次郎、右田健児、安部武雄、岡部猛、金和中：塑性設計された鋼 構造骨組の弹塑性クリープ熱変形举動、日本建策学会構造系論文報告 集、第368号、pp.68一77、1986.10

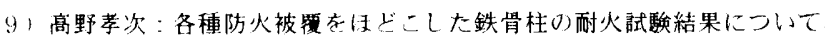
日本建築学会論文報告集、第89号、pp.419、1963.9

10)高野孝次：高温時の鉄骨柱の座屈温度に関する実験、月本建筑学会論文 報告集、第103号、pp.385、1964.10

11) 作本好文、山回種美、岡用忠義、吉田正友、田坂茂樹、斎藤 光：建築 構造用耐火鋼柱す耐火性能に関する実䮖的研究、日本建筑学会構造系論 文報告集、第434号、pp.149 - 158、1992.4

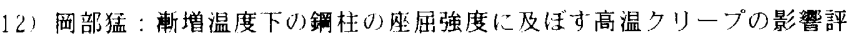
価、構造工学論文集、Vol.43B、pp.367３76、1997.3

13) 岡部猛：矩形断面を持力鋼柱模型(SM490)の高温時の座屈強度、日本建 築学会構造系論文集、第515号、pp.169 171、1999.1

14) 岡部猛 : 鋼構造新素材(SA440B)を用いた柱模型の高温時の座屈強度、日 本建築学会構造系論文集、第521号、pp.169 171、1999.7

15) 岡部猛、安部武雄：建築構造用耐火鋼(NSFR490A)を用いた柱材の高温時 の座屈強度、日本建箘学会構造系論文集、第535号，pp.171-178，2000

16) A.Chaen, T.Ave, T.Okabe: "The Effect of Time on the Buckling Characteristics of Steel Columns Subjected to High Temperatures" , Proceedings of Sixth Pacific Structural Steel Conference, pp. $527 \sim 532$ 2001

17) 岡部猛、安部武雄、立川貴之: 強制部材鱼を受ける鋼柱の高温時の座屈 荷重、構造工学論文集、Vol.49B、pp.375～382、2003.3

(2004年 7 月 1 日原稿受理， 2004 年 10 月 13 日採用決定 